\title{
Implementasi Model Pembelajaran Two Stay Two Stray (TSTS) Untuk Meningkatkan Aspek Kognitif dan Aspek Afektif Mahasiswa Pada Mata Kuliah Akuntansi Keuangan Semester III Kelas A Pagi Program Studi Perbankan Syariah Universitas Muhammadiyah Sumatera Utara Tahun Akademik 2015/ 2016
}

\author{
Isra Hayati \\ Dosen Bisnis Manajemen Syariah UMSU \\ (Email: rosminar_lubis@yahoo.co.id)
}

\begin{abstract}
Abstrak
Penelitian ini merupakan penelitian tindakan kelas (PTK) yang bertujuan untuk mengetahui bagaimana proses pelaksanaan pembelajaran Two Stay Two Stray (TSTS) dapat meningkatkan aspek kognitif mahasiswa yang diukur melalui hasil belajar mahasiswa dan aspek afektif mahasiswa materi Akuntansi Keuangan Semester III A Kelas Pagi Program Studi Perbankan Syariah Fakultas Agama Islam Universitas Muhammadiyah Sumatera Utara. Lima tahapan pembelajaran model pembelajaran Two Stay Two Stray (TSTS )terdiri dari aspek partisipasi, aspek penilaian/penentuan sikap, aspek organisasi, aspek pembentukanpola hidup

Hasil penelitian menunjukkan bahwa penerapan Two Stay Two Stray (TSTS) dapat meningkatkan aspek kognitif mahasiswa dan aspek afektif mahasiswa Semester III A Kelas Pagi Program Studi Perbankan Syariah Fakultas Agama Islam Universitas Muhammadiyah Sumatera Utara mata kuliah Akuntansi Keuangan. Pada siklus I terdiri dari lima tahapan aspek afektif mahasiswa yaitu aspek penerimaan nilai rata-rataobservasi sebesar 95; aspek partisipasi nilai rata-ratanya sebesar 93,5; aspek penilaian/penentuan sikap nilai rata-ratanya sebesar 97; aspek organisasi nilai rata-ratanya sebesar 95; aspek pembentukanpola hidup nilai rataratanya sebesar 96,5. Aspek kognitif yang diukur melalui hasil belajar menunjukkan peningkatan hasil belajar mencapai $93,18 \%$ dari pra tindakan.
\end{abstract}

Kata Kunci: Learning Cycle, refleksi.

Korespondensi: FAI Universitas Muhammadiyah Sumatera Utara Jalan Kapten Mukhtar Basri No. 03 Medan

\section{A. Pendahuluan}

Akuntansi Keuangan sebagai salah satu mata kuliah lanjutan dari mata kuliah pengantar akuntansi yang tedapat pada setiap kurikulum perbankan syariah di Indonesia yang mempunyai peranan penting. Hal ini ditandai dengan dijadikannya mata kuliah akuntansi keuangan ini sebagai salah satu mata kuliah kompetensi utama yang terdapat pada kurikulum perbankan syariah yang harus dimiliki mahasiswa perbankan syariah. Mata kuliah ini menyajikan materi tentang perlakuan akuntansi untuk transaksitransaksi yang dilakukan terutama oleh lembaga keuangan syariah. Disamping itu, materi lainnya berupa standar akuntansi seperti yang diterbitkan oleh Ikatan Akuntan 
Implementasi Model Pembelajaran Two Stay Two Stray (TSTS) Untuk Meningkatkan Aspek Kognitif dan Aspek Afektif Mahasiswa Pada Mata Kuliah Akuntansi Keuangan Semester III Kelas A Pagi Program Studi Perbankan Syariah Universitas Muhammadiyah Sumatera Utara Tahun Akademik 2015/ 2016 ( Isra

Hayati )

Indonesia dan Accounting and Auditing Organization for Islamic Financial Institution (AAOIFI) juga disampaikan dan bahkan melatih mahasiswa untuk mempraktikkan perlakuan akuntansi dari standarstandar tersebut sesuai dengan Pernyataan Standar Akuntansi Keuangan (PSAK). Tujuan dari mata kuliah Akuntansi Keuangan untuk memberikan kerangka dasar bagi mahasiswa yang ingin berkarier sebagai praktisi keuangan. ${ }^{1}$

Pada kenyataannya untuk mencapai tujuan tersebut tidaklah mudah. Permasalahan pembelajaran yang masih didominasi model pembelajaran konvensional, yang umumnya dipacu oleh batas capaian kuantitas materi, teacher oriented, dan cenderung mengesampingkan pengetahuan awal dari pebelajar. Evaluasi lebih berfokus pada aspek kognitif dan aspek afektif yang relatif masih rendah, sebagai akibat jarangnya mahasiswa dihadapkan pada lingkungan belajar yang bernuasa tantangan dengan tuntutan tingkat kemampuan kognitif dan afektif yang lebih tinggi. ${ }^{2}$ Akibatnya, pembelajaran konvensional tidak

\footnotetext{
${ }^{1}$ Sugiarto dkk. (2013). Akuntansi Keuangan. Universitas Terbuka: Jakarta, hlm. 32

${ }^{2}$ Delima.(2011). Penilaian Hasil Proses Belajar Mengajar. Bandung: Remaja Rosdakarya, hlm. 25
}

mampu mengembangkan kemampuan mahasiswa secara optimal.

Selainitu,ditinjaudari metode pembelajaran, dosen masih menerapkan metode pembelajaran ceramah-resitasi. Pada saat masuk kelas, dosen memberikan sedikit ceramah tentang materi pelajaran yang telah dicatat sebelumnya, kemudian dilanjutkan dengan memberi mahasiswa beberapa latihan soal atau tugas. Mahasiswa diminta untuk membuka buku catatan dan mengerjakan latihan soal, atau menjawab pertanyaan yang diajukan oleh dosen. Proses pembelajaran dengan metode konvensional ceramah-resitasi masih belum cukup memberikan kesan yang mendalam pada mahasiswa, karena peran dosen dalam menyampaikan materi lebih dominan dibandingkan keaktifan mahasiswa sendiri. Dosen lebih banyak memberikan penjelasan dari pada mencari tahu sejauh mana mahasiswa bisa menerima dan memahami informasi yang disampaikan. Selain itu juga jumlah persentase hasil belajar ujian semester ganjil mata kuliah pengantar akuntansi semester I kelas A Pagi Program Studi Perbankan Syariah yang berhasil mencapai dan melampaui kategori nilai baik (>75-79) hanya $20 \%$ atau sebanyak 9 mahasiswa.

Berikut tabel distribusi nilai pengantar akuntansi ujian semester ganjil semester I Kelas A Pagi 
Program Studi Perbankan Syariah Tahun Akademik 2014/ 2015:

Nilai ujian semester ganjil Pengantar Akuntansi Semester I Kelas A Pagi Program Studi Perbankan Syariah

\begin{tabular}{|c|c|c|c|}
\hline Nilai & F & $\%$ & $\begin{array}{c}\text { Kategori } \\
\text { Nilai }\end{array}$ \\
\hline $85-100$ & 0 & 0 & $\mathrm{~A}$ \\
\hline $80-84$ & 2 & 4,44 & $\mathrm{~B} / \mathrm{A}$ \\
\hline $75-79$ & 7 & 15,56 & $\mathrm{~B}$ \\
\hline $70-74$ & 15 & 33,33 & $\mathrm{C} / \mathrm{B}$ \\
\hline $65-69$ & 14 & 31,11 & $\mathrm{C}$ \\
\hline $60-64$ & 3 & 6,67 & $\mathrm{D} / \mathrm{C}$ \\
\hline $55-59$ & 4 & 8,89 & $\mathrm{D}$ \\
\hline Jumlah & 45 & $100 \%$ & \\
\hline
\end{tabular}

Sumber: Biro Fakultas Agama Islam UMSU

Dari tabel hasil ujian semester ganjil pengantar akuntansi diatas terdiri dari 4 ranah aspek kognitif yaitu pengetahuan, pemahaman, penerapan dan analisis menunjukkan bahwa jumlah persentase nilai mahasiswa yang berhasil mencapai dan melampaui kategori nilai baik (> 75-79) hanya $20 \%$ yang berjumlah 9 orang mahasiswa. Jumlah persentase nilai keseluruhan mahasiswa dikatakan berhasil dalam proses pembelajaran apabila jumlah persentase nilai mencapai dan melampaui kategori nilai baik (> 7579) sebanyak $80 \%$. Persentase nilai mahasiswa yang belum mencapai kategori nilai baik (<75-79) sebanyak $80 \%$, hal ini menunjukkan aspek kognitif mahasiswa juga rendah.
Olehsebabitu, dosen harus mempunyai kreativitas tinggi dalam memilih model pembelajaranyang menarik minat mahasiswa. Ada dugaan bahwa pola pembelajaran secara parsial dari sistem dan prosedur saat mengikuti kuliah kuliah prasyarat untuk mengikuti praktikum akuntansi menimbulkan ketidak mampuan mahasiswa menggabungkan kemampuan kuliah kuliah prasyarat itu menjadi satu kesatuan yang tersistem sebagai kegiatan yang prosedural dan sistematik. Akibatnya uji transfer dari penguasan kemampuan para mahasiswa dalam menghubungkan semua mata kuliah akuntansi masih lemah seperti mata kuliah pengantar akuntansi, akuntansi keuangan, akuntansi biaya dan akuntansi syariah. Kenyataan dilapangan penekanan proses pembelajaran diperguruan tinggi lebih banyak berkaitan dengan hasil penyelesaian masalah, tetapi kurang berkaitan dengan mengapa demikian dan implikasinya, sehingga basis pemahaman dalam pembelajaran hanya berupa hafalan saja, bukannya penalaran dan kemampuan berfikir sebagai basis pemahaman agar dapat memahami mata kuliah prasyarat berikutnya (Suratno,2007). Sehingga, kemampuan berfikir kritis mahasiswa menjadi terhambat.

Dalam hal ini mahasiswa kurang untuk memperoleh pengalaman langsung dalam pembelajaran sehingga aspek afektif 
Implementasi Model Pembelajaran Two Stay Two Stray (TSTS) Untuk Meningkatkan Aspek Kognitif dan Aspek Afektif Mahasiswa Pada Mata Kuliah Akuntansi Keuangan Semester III Kelas A Pagi Program Studi Perbankan Syariah Universitas Muhammadiyah Sumatera Utara Tahun Akademik 2015/ 2016 ( Isra Hayati )

mahasiswa juga terlihat kurang. Temuan yang menunjukkan bahwa aspek afektif mahasiswa yang masih rendah pada saat proses pembelajaran terlihat dari hal-hal yang dilakukan mahasiswa sebagai berikut:

1. Sikap penerimaan, pada sikap penerimaan mahasiswa masih kurang baik, hal ini terlihat dari respon mahasiswa terhadap penjelasan dosen dan pendapat mahasiswa lainnya yang terkesan cuek dan kurang memperhatikan, mahasiswa lebih menyukai mengobrol dengan temannya dan bermain smartphone. Hal ini disebabkan sebagian besar mahasiswa mempunyai pemikiran sulit belajar akuntansi karena berhitung dan tidak mempunyai basic akuntansi. Sikap penerimaan mahasiswa masih kurang baik lainnya yang ditunjukkan mahasiswa ketika terdapat mahasiswa yang salah memberikan jawaban dari pertanyaan dosen, maka mahasiswa lainnya menertawakan dan bersorak .

2. Sikap partisipasi, pada sikap partisipasi mahasiswa masih kurang baik, hal ini terlihat pada saat dosen memberikan quiz dan latihan, sebagian besar mahasiswa tidak berusaha mencoba mengerjakan karena tidak punya buku pegangan ataupun buku catatan, mahasiswa hanya menunggu jawaban dari temannya yang telah menyelesaikan. Hal ini menunjukkan kurangnya keaktifan mahasiswa dalam menyelesaikan tugas.

3. Penentuan sikap, penentuan sikap mahasiswa terhadap rangsangan yang datang masih rendah. Hal ini ditunjukkan dengan rendahnya respon mahasiswa dalam menanggapi pertanyaan dari dosen.

4. Sikap organisasi, sikap organisasi yang dimiliki mahasiswa masih rendah. Hal ini ditunjukkan dengan masih banyaknya mahasiswa yang tidak dapat membentuk dirinya dalam sebuah kelompok pada saat dosen membentuk model pembelajaran diskusi kelompok, mahasiswa masih meminta dosen untuk menyusun kelompok belajar. Hal ini menunjukkan kurang mandiri dalam mengorganisasikan dirinya.

5. Sikap pembentukan pola hidup, sikap pembentukan pola hidup mahasiswa juga belum menunjukkan hal yang positif. Hal ini ditunjukkan dengan minimnya pembendaharaan pengetahuan mahasiswa terhadap materi pembelajaran karena mahasiswa tidak mempunyai catatan ataupun buku pegangan,bahkan mahasiswa kurang berminat mengunjungi perpustakaan.

Upaya untuk meningkatkan aspek kognitif maupun aspek efektif mahasiswa dapat dilakukan dengan pembelajaraan kooperatif, pembelajaran kooperatif (cooperative 
learning) merupakan pendekatan pengajaran melalui penggunaan kelompok kecil siswa untuk bekerja sama dalam memaksimalkan kondisi belajar dan mencapai tujuan belajar. ${ }^{3}$ Pada umumnya hasil penelitian dari penggunaan metode pembelajaran kooperatif akan menghasilkan prestasi yang lebih tinggi, hubungan yang lebih positif, dan penyesuaian psikologis yang lebih baik dari pada suasana belajar yang penuh dengan persaingan dan memisahmisahkansiswa. ${ }^{4}$

$$
\text { Salah satu model }
$$

pembelajaran kooperatif adalah model twostay twostray (TSTS), dimana model two stay two stray (TSTS) memiliki kelebihanya itu keterlibatan mahasiswa sangat besar dalam proses pembelajaran. Dosen hanyaberperan sebagai fasilitator, artinya tidak ada campur tangan dosen yang terlalu jauh dalam penyampaian materi terhadap mahasiswa. Dari sini maha siswa diharapkan keaktifannya dalam diskusi untuk memecahkan masalah dari materi yang dipelajarinya. Kemampuan akademik mahasiswa yang heterogen dimanfaatkan sebagai acuan untuk membentuk kelompok belajar kooperatif. Tahapan dalam pembelajaran kooperatif model twostaytwostray (TSTS) adalah

Nurhadi,dkk.2004.Pembelajaran Kontekstual dan Penerapannya dalam KBK. Malang:UMPress, hlm. 13

4 Lie. 2002. Mempraktekkan Cooperative learning di Ruang-ruang Kelas.Jakarta: PT.Gramedia, hlm. 54 persiapan, presentasi guru, kegiatan kelompok, presentasi kelasdan evaluasi.

Pembelajaran sekarang harus melibatkan otak untuk berfikir disebut sebagai aspek kognitif dan hati untuk merasakannya disebut sebagai aspekafektif. ${ }^{5}$ Aspek kognitif mencakup tingkat kecerdasan, dayakreatifitas, bakat khusus, kemampuan berbahasa, daya fantasi dan gaya belajar.

Aspek afektif berhubungan dengan penggunaan hati. Yang harus menggunakan hati dalam proses pembelajaran tidak hanya siswa, tetapi juga guru ${ }^{6}$. Sikap guru lebih ditekankan ketika proses belaja rmengajar berlangsung. Guru mempunyai kewenangan untuk menciptakan suasana dan iklim dikelas.

Dengan adanya model pembelajaran two stay two stray mahasiswa tidak perlu hanya bergantung kepada dosen tetapi dapat belajar secara mandiri maupun kelompok untuk saling bertukar fikiran dengan teman sekelasnya sehingga dapat meningkatkan aspek kognitif dan aspek afektif siswa.

Berdasarkan uraian tersebut, maka sebagai upaya untuk meningkatkan aspek kognitif dan aspekafektif mahasiswa, peneliti

${ }^{5}$ Singgih D. 2005. Konseling dan Psikoterapi, Jakarta: Gunung Mulia, hlm. 29

${ }^{6}$ Jagiyanto. 2006. Psikologi Kognitif, Yogyakarta: Pustaka Pelajar, hlm.35 
Implementasi Model Pembelajaran Two Stay Two Stray (TSTS) Untuk

Meningkatkan Aspek Kognitif dan Aspek Afektif Mahasiswa Pada Mata Kuliah Akuntansi Keuangan Semester III Kelas A Pagi Program Studi Perbankan Syariah Universitas Muhammadiyah Sumatera Utara Tahun Akademik 2015/ 2016 ( Isra

Hayati )

merasa perlu melakukan penelitian yang berjudul “ Implementasi Model Pembelajaran Two Stay Two Stray (TSTS) Untuk Meningkatkan Aspek Kognitif Dan Aspek Afektif Mahasiswa Pada Mata Kuliah Akuntansi Keuangan Semester III Kelas A Pagi Program Studi Perbankan Syariah Universitas Muhammadiyah Sumatera Utara Tahun Akademik 2015/ 2016

\section{B. Kajian Pustaka}

Pembelajaran kooperatif sesuai dengan fitrah manusia sebagai sosial yang penuh ketergantungan dengan orang lain, mempunyai tujuan dan tanggung jawab bersama, pembagian tugas, dan rasa senasib. Dengan memanfaatkan kenyatan itu, belajar berkelompok secara kooperatif, siswa dilatih dan dibiasakan untuk saling berbagi (sharing) pengetahuan, pengalaman, tugas, dan tanggung jawab. Saling membantu dan berlatih berinteraksikomunikasi- sosialisasi karena kooperatif adalah miniatur dari hidup bermasyarakat, dan belajar menyadari kekurangan dan kelebihan masing-masing ${ }^{7}$ mengungkapkan:

Cooperative learning offers many benefit: for students, itim proves both academic learning and social skills; for teachers, itis an aidt o classroom

\footnotetext{
7 Ornstein, Allan C. dan Thomas J. Lasley, II. (2000). Strategies for EffectiveTeaching. TheMcGraw-Hill HigherEducation: USA.
}

management an dinstruction. Cooperative learning enhances student's enthusiasm for learning and their determination to achieve academic success.

Jadi, pembelajaran kooperatif dapat menumbuhkan kemampuanbelajar dan kemampuan bersosialisasi juga dapat menumbuhkan antusias atau minat siswa dalam mengikuti pembelajaran. Hal tersebut hampir sama dengan pendapat yang menyatakan bahwa:

Cooperative learning is known tobe an effective education alstrategy in enhancing the learning performance of students ${ }^{8}$ The goal of a cooperative learning group is to maximize allmembers' learning efficacy. This is accomplished via promoting each other's success, through assisting, sharing, mentoring, explaining, and encouragement.

Dengan demikian, pembelajaran kooperatif dikenal sebagai strategi pembelajaran yang efektif dalam meningkatkan partisipasi siswa. Tujuan kelompok dalam pembelajaran kooperatif adalah memaksimalkan agar semua

$\begin{array}{lrr} & & \\ & & \\ & \text { Hwang,G.-J.,Yin,P.-Y.,Hwang,C.- } \\ \text { W.,\& } & \text { Tsai,C.-C.(2008).“An } & \text { Enhanced } \\ \text { GeneticApproachtoComposing } & \\ \text { CooperativeLearning } & \text { Groupsfor } \\ \text { MultipleGroupingCriteria”.EducationalTechn } \\ \text { ology\&Society,11(1),148-167. } & \text { Dalam } \\ \text { http://www.ifest.info/, diakses } & \text { pada8 } \\ \text { Desember2009 } & \end{array}$


siswa bisa lebih baik.Setiap siswa yang pandai mengajak yang lainnya agar sukses, melalui membantu, berbagi, menasehati, menjelaskan, dan memberikan semangat.

Teknik belajar Two Stay Two Stray (Dua Tinggal Dua Tamu) dikembangkan oleh Spencer Kagan (1992) bisa digunakan dalam semua mata pelajaran dan untuk semua tingkatan usia peserta didik. ${ }^{9}$ Struktur Two Stay Two Stray memberi kesempatan kepada kelompok untuk membagikan hasil dan informasi dengan kelompok lain. Banyak kegiatan belajar mengajar yang diwarnai dengan kegiatan-kegiatan individu. Siswa bekerja sendiri dan tidak diperbolehkan melihat pekerjaan siswa yang lain. Padahal dalam kenyataan hidup di luar sekolah, kehidupan dan kerja manusia saling bergantung satu dengan yang lainnya.

Cara Menerapkan teknik Two StayTwo Stray yaitu:

1. Siswa bekerja sama dalam kelompok berempat seperti biasa.

2. Setelah selesai, dua orang dari masing-masing kelompok akan meninggalkan kelompoknya dan masing-masing bertamu ke dua kelompokyanglain.

3. Dua orang yang tinggal dalam kelompok bertugas membagikan hasil kerja dan

${ }^{9}$ Anita.2008.CooperativeLearning:Me mpraktikkanCooperativeLearningdiRuangRuang Kelas. Jakarta: PT Grasindo,hlm. 16 informasi mereka ketamu mereka.

4. Tamu mohon diri dan kembali ke kelompok mereka sendiri dan melaporkan temuan merekadari kelompok lain.

5. Kelompok mencocokkandan membahas hasil-hasil kerjamereka.

Sejalan dengan hal tersebut, pembelajaran dengan metode itu diawali dengan pembagian kelompok. ${ }^{10}$ Tahapan dalam pembelajaran kooperatif metode two stay two stray (TSTS) adalah persiapan, presentasi guru, kegiatan kelompok, presentasi kelas dan evaluasi. Pada tahap persiapan siswa akan dituntut untuk selalu hadir dalam pembelajaran dan datang tepat waktu, siswa juga dituntut untuk selalu membawa bahan ajar berupa buku Akuntansi Keuangan dari berbagai penerbit yang akan digunakan oleh kelompoknya untuk menyelesaikan tugas permasalahan sebagai bahan diskusi. Tahapan selanjutnya adalah tahapan inti dari metode lembelajaran two stay two stray (TSTS) yaitu diskusi kelompok.

\section{Metode}

Siklus I direncanakan dalam 4 kali pertemuan yaitu 3 kali pertemuan untuk pelaksanaan tindakan dan 1 kali pertemuan untuk pelaksanaan

\begin{tabular}{|c|c|c|}
\hline 10 & Suprijono,A.2009. & Cooperative \\
\hline Learning & Teori dan & Aplikasi \\
\hline
\end{tabular}


Implementasi Model Pembelajaran Two Stay Two Stray (TSTS) Untuk Meningkatkan Aspek Kognitif dan Aspek Afektif Mahasiswa Pada Mata Kuliah Akuntansi Keuangan Semester III Kelas A Pagi Program Studi Perbankan Syariah Universitas Muhammadiyah Sumatera Utara Tahun Akademik 2015/ 2016 ( Isra

Hayati )

tes. Alokasi waktu untuk masingmasing pertemuan adalah $3 \times 50$ menit. Kegiatan- kegiatan yang dilaksanakan dalam siklus I dijabarkan sebagaiberikut:

1. Tahap perencanaan,meliputi:

a. Membuat Satuan Acara Perkuliahan (SAP) sesuai dengan modelpembelajaranTwo Stay Two Stray (TSTS).

b. MembuatLembar Kerja Siswa (LKS) sesuai dengan model pembelajaran Two Stay Two Stray (TSTS).

c. Penyusunan instrumen penelitian berupa Lembar Pengamatan

PengelolaanPembelajaran dalam pembelajaran yang menggunakan

modelpembelajaran Two Stay Two Stray (TSTS).

d. Penyusunan instrumen penelitian berupa Lembar Pengamatan Aspek Afektif mahasiswa menggunakanmodelpembelaj aran Two Stay Two Stray (TSTS).yangdilaksanakan oleh dosen.

e. Membuatsoalteshasil belajar yang mencakup enam ranah aspek kognitif yakni pengetahuan, pemahaman, penerapan, analisis, sintesis, danevaluasipada akhir siklusuntuk mengukur aspek kognitif besertadengan kuncijawabandan rubrik penilaiannya.

f. Melakukan pertemuan pendahuluan dengan anggota penelitian yang juga membawakan mata kuliah Akuntansi Keuangan untuk membantu pengamatan pelaksanaan tindakan untuk mendiskusikan hal-hal yang dianggap perlu untuk diketahui dan disepakati agar bantuan yang diberikan pada penelitian tindakan kelas ini dapat bermanfaat secara maksimal.

2. Tahap pelaksanaan, meliputi:

a.Melaksanakankegiatanpembelaja ransesuaidenganSAPyangtelah disusun.

b.Pelaksanaan tindakan dilakukan secara bersamaan dengan kegiatan pegamatan (observasi) untuk pengelolaan pembelajaran dan pengamatan aspek afektif mahasiswa yang dilakukan oleh dosen, sesuai dengan rencana yang telah disusun

c.Melaksanakantesakhir siklusI.

3. Observasi

Observasi (pengamatan)

dilaksanakan secara kolaboratif antara peneliti dengan rekan peneliti. Observasi dilaksanakan selama proses pembelajaran berlangsung. Kegiatan yang dilakukan dalam observasi meliputi pengamatan terhadap keterlaksanaan pembelajaran, hambatan yang ditemui, 
kemampuan hasil belajar mahasiswa, dan mencatat segalaaktivitas mahasiswadikelas.

\section{Refleksi}

Pada tahap ini dilakukan evaluasi terhadap proses yang terjadi serta hambatan yang muncul selama tindakan agar peneliti dapat menindak lanjuti dengan melakukan upaya perbaikan untuk tindakan pada siklus berikutnya. Refleksi dilakukan dengan menggabungkan pemikiran dan pendapat dari rekan peneliti sesuai dengan hasil observasi yang diperoleh. Apabila hasil yang diperoleh belum memenuhi inikator keberhasilan, makahasildarirefleksi inidijadikan dasar untuk perbaikan pada siklus berikutnya.

\section{Hasil Penelitian}

\section{Deskripsi Hasil Penelitian Pra Tindakan}

Penelitian berlangsung sebanyak dua siklus yang setiap siklusnya terdiri dari tiga kali pertemuan untuk tindakan dan satu kali pertemuan untuk tes akhir siklus. Pokok bahasan yang dipelajari adalah rekonsiliasi Bank. Jumlah mahasiswa semester III Kelas A Pagi Program Studi Perbankan Syariah Fakultas Agama Islam UMSU pada semester ganjil berjumlah 44 mahasiswa. Setelah dilakukan kegiatan perkuliahan pada mata kuliah Akuntansi Keuangan materi rekonsiliasi bank di Program Studi Perbankan Syariah Fakultas Agama Islam UMSU dalam kegiatan pra tindakan, maka untuk menguji pengetahuan awal mahasiswa dalam mengukur aspek kognitif mahasiswi, maka peneliti terlebih dahulu melaksanakan tes dengan mengujikan 15 soal pilihan ganda kepada mahasiswa mengenai materi rekonsiliasi Bank, dan untuk mengetahui keterampilan mahasiswa dalam melaksanakan materi rekonsiliasi Bank tersebut, peneliti melakukan tes keterampilan dengan melakukan praktek. Dari hasil evaluasi tersebut maka diperoleh hasil belajar untuk mengukur aspek kognitif dari evaluasi yang dilakukan sebagaimana dalam tabel berikut:

\section{Hasil Belajar Pra Tindakan Semester IIIA Kelas Pagi Program Studi Perbankan Syariah}

\begin{tabular}{|c|c|c|l|}
\hline No & Nilai & F & \multicolumn{1}{|r|}{$\%$} \\
\hline 1 & 100 & 0 & 0.0 \\
\hline 2 & 95 & 0 & 0.0 \\
\hline 3 & 90 & 0 & 0.0 \\
\hline 4 & 85 & 2 & 4,54 \\
\hline 5 & 80 & 6 & 13,64 \\
\hline 6 & 75 & 6 & 13,64 \\
\hline 7 & 70 & 15 & 34,09 \\
\hline 8 & 65 & 7 & 15,91 \\
\hline 9 & 60 & 8 & 18,18 \\
\hline 10 & 55 & 0 & 0.0 \\
\hline 11 & 50 & 0 & 0.0 \\
\hline Jumlah & 44 & 100.00 \\
\hline
\end{tabular}


Implementasi Model Pembelajaran Two Stay Two Stray (TSTS) Untuk Meningkatkan Aspek Kognitif dan Aspek Afektif Mahasiswa Pada Mata Kuliah Akuntansi Keuangan Semester III Kelas A Pagi Program Studi Perbankan Syariah Universitas Muhammadiyah Sumatera Utara Tahun Akademik 2015/ 2016 ( Isra

Hayati )

Berdasarkan tabel Hasil Belajar Pra Tindakan Semester III A Pagi Program Studi Perbankan Syariah di atas, hasil perkuliahan mahasiswa dalam mata kuliah Akuntansi Keuangan pada materi rekonsiliasi Bank dalam penelitian tahap pra tindakan menunjukkan bahwa hanya 14 orang yang tuntas atau $(31,82 \%)$, dengan kriteria ketuntasan minimal yaitu nilai 75 , berarti belum memiliki ketuntasan klasikal, karena ketuntasan klasikal baru tercapai apabila 85\% mencapai nilai > 75. Dilihat dari kategori nilai, maka hasil belajar pra tindakan ini tidak terdapat mahasiswa yang memiliki nilai dalam kategori sangat tinggi (93-100), mahasiswa yang memiliki kategori nilai tinggi (84-92) hanya 2 orang mahasiswa , 12 orang mahasiswa memiliki kategori nilai sedang (75-83), dan 15 orang mahasiswa memiliki kategori nilai cukup (70-74).

Pada saat melaksanakan pra tindakan Semester III A Pagi Program Studi Perbankan Syariah, aspek afektif mahasiswa menunjukkan hasil yang rendah juga sebab pada saat proses pembelajaran terlihat dari halhal yang dilakukan mahasiswa sebagai berikut:

1) Sikap penerimaan, pada sikap penerimaan mahasiswa masih belum bisa memusatkan perhatian karena mahasiswa belum menguasai dasar dasar akuntansi dan berasumsi sulit untuk memahami materi akuntansi, sehingga terkesan cuek.

2) Sikap partisipasi, pada sikap partisipasi mahasiswa banyak yang tidak mau berusaha untuk mengerjakan latihan arena tidak paham dan mempunyai mindset mengharapkan dapat mencontek jawaban dari temannya.

3) Penentuan sikap, pada penentuan sikap mahasiswa kurang menunjukkan keaktifan didalam kelas ketika dosen memberikan stimulus.

4) Sikap Organisasi, pada sikap organisasi yang dimiliki mahasiswa belum menunjukkan kekompakkan bekerjasama dalam mengerjakan tugas didalam tim, masih terdapat mahasiswa yang tidak ikut serta dalam mengerjakan tugas, karena merasa belum paham..

5) Sikap pembentukan pola hidup, pada sikap pembentukan pola hidup menunjukkan mahasiswa masih belum tepat waktu dalam mengerjakan tugas dan kehadiran di perkuliahan.

Untuk memecahkan masalah rendahnya aspek kognitif dan aspek afektif mahasiswa semester III A Kelas Pagi pada Program Studi Perbankan Syariah Fakultas Agama 
Islam UMSU, maka diupayakan dengan menggunakan model pembelajaran Two Stay Two Stray (TSTS).

\section{Deskripsi Hasil Penelitian Siklus I}

a. Perencanaan (tahap persiapan)

Sebelum pelaksanaan siklus I, peneliti mendiskusikan beberapa aspek kognitif dan aspek afektif mahasiswa dalam mengikuti proses pembelajaran akuntansi keuangan berdasarkan kegiatan pra tindakan yang telah dilakukan sebelumnya. Berdasarkan diskusi tersebut disimpulkanlah bahwa ada beberapa kendala dalam proses pembelajaran, yakni:

1. Aspek kognitif mahasiswa yang diukur dengan tes hasil belajar yang mencakup aspek pengetahuan, pemahaman, penerapan, analisis, sintesis, danevaluasi masih menunjukkan hasil yang rendah.

2. Aspek afektif mahasiswa masih rendah, hal ini terlihat dari sikap penerimaan, sikap partisipasi, penentuan siap, sikap organisasi, maupun sikap pembentukan pola hidup masih rendah.

3. Mahasiswa dalam pelaksanaan pembelajaran hanya bertanya kepada guru dan tidak diberikan kesempatan bertanya dan berinteraksi dengan temannya.
4. Tidak berminatnya mahasiswa dalam mengikuti pembelajaran akuntansi keuangan, disebabkan kegiatan pembelajaran bersifat monoton dengan mempergunakan metode ceramah.

5. Mahasiswa mempunyai asumsi lemah dalam melaksanakan perkuliahan yang mempunyai unsur menghitung.

Berdasarkan hal tersebut diatas, salah satu upaya yang dapat dilakukan untuk mengatasi hal tersebut adalah dengan pembelajaraan kooperatif, dimana Menurut Holubec pembelajaran koperatif (cooperative learning) merupakan pendekatan pengajaran melalui penggunaan kelompok kecil siswa untuk bekerjasama dalam memaksimalkan kondisi belajar dan mencapai tujuan belajar. Untuk meningkatkan hasil belajar mahasiswa pada mata kuliah akuntansi keuangan, maka pada pelaksanaan perencanaan siklus I dibuat perencanaan sebagai berikut:

1) Menyusun Satuan Acara Perkuliahan SAP Akuntansi Keuangan materi rekonsiliasi bank dengan menerapkan model pembelajaran kooperatif model two stay two stray (TSTS) dengan materi rekonsiliasi bank dalam proses pengembangan kepribadian. SAP yang disusun disesuaikan 
Implementasi Model Pembelajaran Two Stay Two Stray (TSTS) Untuk

Meningkatkan Aspek Kognitif dan Aspek Afektif Mahasiswa Pada Mata Kuliah Akuntansi Keuangan Semester III Kelas A Pagi Program Studi Perbankan Syariah Universitas Muhammadiyah Sumatera Utara Tahun Akademik 2015/ 2016 ( Isra

Hayati )

dengan tahap-tahap yang ada dalam model pembelajaran two stay two stray (TSTS).

Tahap-tahap dalam model pembelajaran two stay two stray (TSTS) yaitu: persiapan, presentasi guru, kegiatan kelompok, presentasi kelas dan evaluasi.

2) Mempersiapkan materi ajar

3) Menyiapkan media pembelajaran yang tepat yang mendukung terhadap pelaksanaan pembelajaran.

4) Menyiapkan lembar kegiatan peserta didik (LKS)

5) Menyusun instumen penelitian:

a) Perangkat soal evaluasi hasil belajar mahasiswa untuk mengukur aspek kognitif mahasiswa sebanyak lima transaksi rekonsiliasi bank.

b) Lembar observasi penerapan pelaksanaan pembelajarantwo stay two stray (TSTS) dan aspek afektif mahasiswa.

\section{b. Pelaksanaan Tindakan Siklus I}

Pelaksanaan tindakan siklus I dilaksanakan pada hari Kamis tanggal 22 Oktober 2015,peneliti memulai siklus I pada pengenalan tentang materi rekonsiliasi bank, dengan menerapkan model pembelajaran two stay two stray (TSTS). Siklus I ini dilakukan selama tiga SKS.

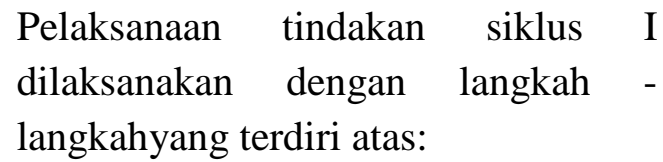

1) Persiapan

Dalam kegiatan persiapan ini dosen membuka kegiatan pembelajaran dengan melakukan apersepsi kepada mahasiswa, kemudian mahasiswa duduk dengan langsung berkumpul sesuai dengan kelompok yang sudah dibentuk pada pertemuan sebelumnya (di luar pembelajaran model two stay two stray (TSTS). Kelompok belajar tersebut terdiri dari empat orang yang memiliki kemapuan tinggi, sedang dan rendah dalam masing masing kelompok. Setelah mahasiswa duduk dengan anggota kelompoknya masing - masing, dosen menjelaskan model pembelajaran yang akan dilaksanakan two stay two stray (TSTS), dimana ketika terdapat kelompok yang kesulitan dalam memecahkan kasus maka dua dari anggota kelompok tersebut dapat mendatangi kelompok lain untuk bertanya, dan dua anggota kelompok lainnya tetap berada didalam kelompok.

2) Presentasi Guru

Dosen menyampaikan materi rekonsiliasi bank berserta 
contoh rekening koran bank agar mahasiswa tertarik terhadap materi yang disampaikan.

3) Kegiatan Kelompok Pada kegiatan kelompok ini, setiap mahasiswa diberikan LKS yang berisikan latihan sesuai dengan materi yang disampaikan dosen. Setiap kelompok mengerjakan LKS tersebut dan mendiskusikannya, kemudian dosen memperhatikan sambil mengelilingi masing -masing kelompok, sambil memberikan arahan agar dapat bertanya kepada kelompok lainnya jika terdapat persoalan yang tidak dapat dipecahkan dalam kelompok (kegiatan bertamu dan menerima tamu). Apabila mahasiswa sudah melakukan kegiatan bertamu kepada kelompok lainnya, maka hasil diskusi dari kegiatan tersebut harus didiskusikan kembali dalam kelompoknya masing masing.

4) Presentasi Kelompok

Dalam kegiatan presentasi kelompok, dosen memberi kesempatan kepada mahasiswauntuk maju dan mempresentasikan jawaban pada LKS tesebut. Kemudian dilakukan diskusi semua kelompok dengan membentuk kegiatan tanya jawab. Dari presentasi ini dosen menunjukkan bahwa agen sosialisasi dalam membentuk kepribadian yang diterima oleh satu mahasiswa maka masing-masing mahasiswa akan mendapat agen-agen sosialisasi yang artinya setiap siswa kembali kepada kelompoknya masing-masing untuk didiskusikan dengan model two stay two stray. Dari permasalahan yang terdapat pada LKS dan tambahan materi yangditambahkan dosen untuk didiskusikan hasilnya, maka mahasiswa merasa sangat puas,hal ini terlihat dengan semangat dan keriangan mahasiswa pada saat didiskusikan oleh dosen mereka.

5) Evaluasi

Pada kegiatan evaluasi ini setiap mahasiswa selama pelaksanaan tindakan I, diberikan posttest untuk dapat mengetahui aspek kognitif mahasiswa. Dosen sudah berusaha menerapkan semua tahapan-tahapan yang ada pada model pembelajaran two stay two stray (TSTS) atau sesuai dengan sintaks model pembelajaran two stay two stray (TSTS) dengan maksimal. Kemudian melakukan observasi pada siklus I untuk mengukur aspek afektif mahasiswa. Setelah pelaksanaan siklus I ini, maka 
Implementasi Model Pembelajaran Two Stay Two Stray (TSTS) Untuk Meningkatkan Aspek Kognitif dan Aspek Afektif Mahasiswa Pada Mata Kuliah Akuntansi Keuangan Semester III Kelas A Pagi Program Studi Perbankan Syariah Universitas Muhammadiyah Sumatera Utara Tahun Akademik 2015/ 2016 ( Isra Hayati )

akan diketahui bagaimana pencapaian aspek kognitif dan aspek afektif mahasiswa.

\section{c. Hasil Observasi dan Tes Hasil Belajar Siklus I}

1) Data hasil lembar observasi keterlaksanaan pembelajaran two stay two stray (TSTS) Berdasarkan hasil observasi peneliti terhadap pelaksanaan perkuliahan pada materi rekonsiliasi bank dengan menggunakan model pembelajaran two stay two stray (TSTS), dapat diketahui bahwa:

DataHasilKeterlaksanaan Pembelajaran SiklusI

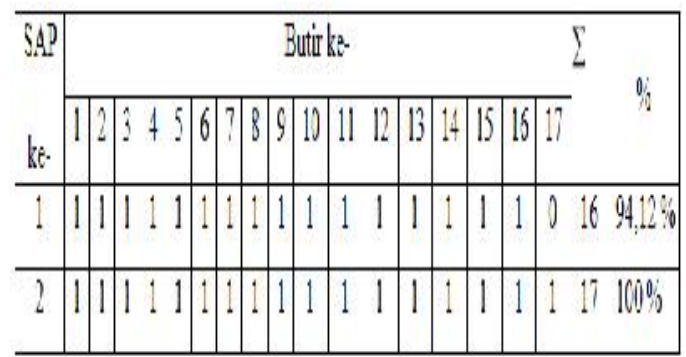

Dari data di atas dapat dilihat bahwa rata-rata keterlaksanaan SAP siklusI adalah97,06\%. Butir yang tidak terlaksana pada SAP ke-1 adalah butir 17 yaitu pada saat pelaksanaan post test. Pada mahasiswa di setiap kelompok mendapatkan permasalahan yang tahap evaluasi pada SAP ke -1 . Ketidak terlaksanaan poin ini disebabkan karena mahasiswa tidak dapat mengatur waktu agar dapat selesai mengerjakan post test sesuai dengan waktu yan telah ditentukan. Hal ini tidak terlaksana karena keterbatasan waktu.

Pada SAP ke-2 semua butir dapat terlaksana dengan baik mencapai $100 \%$. Seluruh mahasiswa menunjukkan bukti-bukti dan klarifikasidari penjelasan mereka ketika presentasi dan mengerjakan evaluasi. Hal ini terlaksana dikarenakan mahasiswa sudah lebih memahami tahapan model pembelajaran two stay two stray (TSTS), dan dosen melaksanakan model pembelajaran two stay two stray (TSTS) dengan maksimal.

\section{2) Data hasil lembar observasi aspek afektif mahasiswa selama mengikuti kegiatan pembelajaran model pembelajaran two stay two stray (TSTS)}

Berdasarkan hasil pengamatan terhadap pelaksanaan proses belajar mengajar rekonsiliasi bank, diperoleh gambaran tentang aspek afektif mahasiswa selama kegiatan belajar mengajar berlangsung, sebagai berikut: nilai total rata-rata aspek afektif yang diperoleh dari lembar observasi pada saat proses pembelajaran adalah 95,4, dengan rincian bahwa aspek penerimaan nilai rata-ratanya sebesar 95; aspek partisipasi nilai rata-ratanya sebesar 93,5; aspek penilaian/penentuan sikap nilai rata-ratanya sebesar 97; aspek 
organisasi nilai rata-ratanya sebesar 95; aspek pembentukan pola hidup nilai rata-ratanya sebesar 96, 5 .

\section{Pencapaian Aspek Afektif pada Siklus I}

\begin{tabular}{|c|c|c|c|}
\hline No & $\begin{array}{l}\text { Kategori } \\
\text { Perilaku }\end{array}$ & Indikator & $\begin{array}{l}\text { Nilai } \\
(0- \\
\text { 100) }\end{array}$ \\
\hline 1 & Penerimaan & $\begin{array}{l}\text { Respon } \\
\text { terhadap } \\
\text { pendapat } \\
\text { siswa }\end{array}$ & 95 \\
\hline \multirow[t]{2}{*}{2} & \multirow[t]{2}{*}{ Partisipasi } & $\begin{array}{l}\text { Keaktifan } \\
\text { dalam } \\
\text { mencari } \\
\text { Jawaban }\end{array}$ & 92 \\
\hline & & $\begin{array}{l}\text { Keaktifan } \\
\text { dalam } \\
\text { diskusi }\end{array}$ & 95 \\
\hline 3 & $\begin{array}{l}\text { Penentuan } \\
\text { Sikap }\end{array}$ & $\begin{array}{l}\text { Keaktifan } \\
\text { bertanya } \\
\text { atau } \\
\text { menjawab }\end{array}$ & 97 \\
\hline 4 & Organisasi & $\begin{array}{l}\text { Kerjasama } \\
\text { dalam } \\
\text { kelompok }\end{array}$ & 95 \\
\hline \multirow[t]{2}{*}{5} & \multirow[t]{2}{*}{$\begin{array}{l}\text { Pembentuka } \\
\text { n } \\
\text { pola hidup }\end{array}$} & $\begin{array}{l}\text { Kehadiran } \\
\text { saat proses } \\
\text { Pembelajara } \\
\text { n }\end{array}$ & 97 \\
\hline & & $\begin{array}{l}\text { Kelengkapa } \\
\mathrm{n} \text { alat dan } \\
\text { sumber } \\
\text { Belajar }\end{array}$ & 96 \\
\hline
\end{tabular}

\section{3) Data Hasil Belajar mencakup enam ranah aspek kognitif}

Siklus I dianggap sukses atau efektif apabila mahasiswa mendapat nilai $\geq 75$, atau secara klasikal $85 \%$ mahasiswa tuntas dalam perkuliahan. Dari tindakan yang sudah dilaksanakan pada siklus I, pada akhir pembelajaran diberi tes hasil belajar. Hasil pembelajaran mahasiswa yang telah mendapat perlakuan pembelajaran dengan menggunakan model pembelajaran Two Stay Two Stray pada siklus I, dapat dilihat pada tabel berikut:

\section{Hasil Belajar Siswa Siklus I}

\begin{tabular}{|c|c|c|c|}
\hline No & $\begin{array}{c}\text { Nila } \\
\text { i }\end{array}$ & F & \% \\
\hline 1 & 100 & 0 & 0.0 \\
\hline 2 & 95 & 2 & 4,5 \\
\hline 3 & 90 & 6 & 13,64 \\
\hline 4 & 85 & 8 & 18,18 \\
\hline 5 & 80 & 10 & 22,73 \\
\hline 6 & 75 & 15 & 34,09 \\
\hline 7 & 70 & 2 & 4,5 \\
\hline 8 & 65 & 1 & 2,27 \\
\hline 9 & 60 & 0 & 0,0 \\
\hline 10 & 55 & 0 & 0,0 \\
\hline 11 & 50 & 0 & 0,0 \\
\hline \multicolumn{2}{|c|}{} & & 100,0 \\
\multicolumn{2}{|c|}{ Jumlah } & 44 & 0 \\
\hline
\end{tabular}

Berdasarkan tabel di atas, dapat diketahui bahwa hasil belajar mahasiswa dalam mata kuliah akuntansi keuangan materi rekonsiliasi bank pada siklus I menunjukkan bahwa 41 orang yang tuntas atau $(93,18 \%)$, dengan kriteria ketuntasan minimal yaitu nilai 75 , 
Implementasi Model Pembelajaran Two Stay Two Stray (TSTS) Untuk Meningkatkan Aspek Kognitif dan Aspek Afektif Mahasiswa Pada Mata Kuliah Akuntansi Keuangan Semester III Kelas A Pagi Program Studi Perbankan Syariah Universitas Muhammadiyah Sumatera Utara Tahun Akademik 2015/ 2016 ( Isra Hayati )

berarti hasil belajar mahasiswa semester III kelas A Kelas Pagi Program Studi Perbankan Syariah memiliki ketuntasan klasikal, karena ketuntasan klasikal tercapai apabila $85 \%$ siswa mencapai nilai 75. Dilihat dari kategori nilai, maka hasil belajar pada siklus I ini, terdapat 8 orang mahasiswa yang memiliki nilai dalam kategori sangat tinggi (93-100), mahasiswa yang memiliki kategori nilai tinggi (84-92) hanya 8 orang mahasiswa, 25 orang mahasiswa memiliki kategori nilai sedang (7583), dan 3orang mahasiswa memiliki kategori nilai cukup (70-74).

Pada siklus I ini, hasil belajar mahasiswa mengalami peningkatan, dibandingkan dengan hasil yang didapat pada tahap pra tindakan, yaitu melalui pelaksanaan pembelajaran dengan menggunakan model pembelajaran Two Stay Two Stray. Dengan demikian, dikarenakan kriteria ketuntasan mahasiswa telah tercapai maka siklus di hentikan hanya sampai dengan siklus I saja.

\section{4) Refleksi Hasil Tindakan Siklus I}

Refleksi ini dilakukan untuk menentukan apakah tindakan siklus I harus diulangi atau telah mencapai tingkat keberhasilan. Dalam pelaksanaan kegiatan belajar mengajar diperoleh informasi dari hasil pengamatan adalah:

a. Berdasarkan hasil yang diperoleh dari observasi keterlaksanaan pembelajaran Two Stay Two Stray, bahwa rata - rata keterlaksanaan pembelajaran Two Stay Two Stray mencapai $97,06 \%$ pada siklus I ini, ketidakterlaksanaan 2,94\% . Hasil persentase ini menunjukkan bahwa mahasiswa memberikan respon sangat positif karena mahasiswa dapat memahami materi perkuliahan yang disampaikan dengan baik.

b. Aspek kognitif mahasiswa yang diukur melalui hasil tes akhir pada siklus I diperoleh data bahwa mahasiswa yang mendapat nilai tuntas hanya 41 orang mahasiswa atau (93,18\%), dengan demikian kriteria keberhasilan pembelajaran telah mencapai kriteria yang maksimal sebagaimana telah ditetapkan pada siklus I. Karena ketuntasan klasikal baru tercapai apabila $85 \%$ mencapai nilai KKM, yaitu nilai 75 .

c. Berdasarkan hasil observasi aspek afektif mahasiswa pada siklus I mencapai hasil yang diharapkan dalam hal ini diketahui dari 5 indikatornilai total rata-rata aspek afektif yang diperoleh dari lembar observasi pada saat proses pembelajaran adalah 95,4, dengan rincian bahwa aspek penerimaan nilai rata-ratanya sebesar 95; aspek partisipasi nilai rata-ratanya sebesar 93,5; aspek penilaian/penentuan sikap nilai 


$\begin{array}{lcr}\text { rata-ratanya } & \text { sebesar } 97 ; \text { aspek } \\ \text { organisasi } & \text { nilai } & \text { rata-ratanya } \\ \text { sebesar } & 95 ; & \text { aspek } \\ \text { pembentukanpola } & \text { hidup } & \text { nilai } \\ \text { rata-ratanya } & \text { sebesar } & 96,5 . \text { Dari } \\ \text { keseluruhan aspek afektif } \\ \text { mahasiswa dari pertemuan siklus } \\ \text { I sudah berhasil. }\end{array}$

\subsection{Pembahasan Hasil Penelitian}

Dari hasil temuan yang telah dipaparkan di atas, dapat dikemukakan bahwa Penelitian Tindakan Kelas (PTK) yang dilaksanakan di Program Studi Perbankan Syariah Fakultas Agama Islam UMSU, merupakan salah satu cara untuk menemukan masalah atau problem yang ada khususnya pada mata kuliah akuntansi keuangan. Karena selama ini, mahasiswa kurang berminat dalam mempelajari mata kuliah akuntansi keuangan, khususnya materi rekonsiliasi bank, walaupun dosen telah berusaha untuk memotivasi mahasiswa agar sungguh-sungguh mempelajari materi akuntansi keuangan namun kenyataannya masih banyak dijumpai mahaiswa yang belum mampu melaksanakannya secara baik dan benar. Dengan demikian perlu dikembangkan kepada dosen-dosen yang lain, termasuk mata kuliah yang selama ini dianggap sulit oleh mahasiswa agar dilakukan penelitian tindakan kelas untuk mengungkap masalah yang dihadapi oleh dosen maupun mahasiswa itu sendiri.

Tahap-tahap pelaksanaan pembelajaran model two stay two stray (TSTS) terdiri atas lima tahap utama yaitu persiapan, presentasi guru,kegiatan kelompok, presentasi kelompok, dan evaluasi. Pelaksanaan tahap persiapan dimulai dengan dosen membagi mahasiswa ke dalam kelompok berdasarkandan prestasi akademik. Setelah siswa dibentuk kelompok secara heterogen kemudian guru menjelaskan prosedur pembelajaran model two stay two stray (TSTS) agar siswa mengetahui dan mengenal setiap tahapan dalam pembelajaran model tersebut. Guru juga menjelaskan pentingnya kerja kelompok dalam pelaksanaan diskusi agar siswa belajar dengan baik.

Berdasarkan paparan data dan analisis terdahulu, dapat dikemukakan bahwa ada tiga temuan dalam penelitian ini:

1. Keterlaksanaan model pembelajaran two stay two stray (TSTS) pada mahasiswa Semester III A Kelas Pagi Program Studi Perbankan Syariah Fakultas Agama Islam UMSU memberikan respon yang sangat positif pada siklus I , keterlaksanaan model pembelajaran twostay two stray (TSTS) mencapai 97,06\%, semua tahap pelaksanaan model pembelajaran dapat dilaksanakan dengan baik.

2. Aspek kognitif mahasiswa yang diukur melalui hasil belajar mahasiswa Semester III A Kelas Pagi Program Studi Perbankan Syariah Fakultas Agama Islam UMSU mengalami peningkatan 
Implementasi Model Pembelajaran Two Stay Two Stray (TSTS) Untuk

Meningkatkan Aspek Kognitif dan Aspek Afektif Mahasiswa Pada Mata Kuliah Akuntansi Keuangan Semester III Kelas A Pagi Program Studi Perbankan Syariah Universitas Muhammadiyah Sumatera Utara Tahun Akademik 2015/ 2016 ( Isra

Hayati )

setelah menggunakan Model Pembelajaran twostay two stray (TSTS), yaitu hasil belajar mahasiswa pada kegiatan pra tindakan hanya bahwa hanya 14 orang yang tuntas atau $(31,82 \%)$. Sedangkan pada siklus I hasil belajar mahasiswa mengalami peningkatan dibandingkan dengan kegiatan pra tindakan, yaitu mencapai 41 orang mahasiswa atau (93,18\%),dengan demikian aspek kognitif mahasiswa Semester III A Kelas Pagi Program Studi Perbankan Syariah Fakultas Agama Islam UMSUmengalami peningkatan karena kriteria keberhasilan pembelajaran telah mencapai kriteria yang maksimal sebagaimana telah ditetapkan pada siklus I. Karena ketuntasan klasikal tercapai apabila $85 \%$ mencapai nilai KKM, yaitu nilai 75.

3. Aspek afektif mahasiswa semester III A Kelas Pagi Program Studi Perbankan Syariah Fakultas Agama Islam UMSU mengalami peningkatan setelah menggunakan Model Pembelajaran TwoStay Two Stray (TSTS) yaitu pada siklus I aspek afektif mahasiswa mencapai 95,4.

Jika diperhatikan sesungguhnya penelitian tindakan kelas ini sangat bermanfaat, sehingga setiap mata kuliah atau setiap dosen yang ingin meningkatkan kualitas mahasiswa perlu adanya inovasi yang dilakukan oleh dosen itu sendiri, baik mengenai strategi yang dipakai atau metode yang diterapkannya apakah sudah tepat atau belum. Hal inilah yang terkadang menjadi kendala bagi dosen di dalam melaksanakan pembelajaran di kelas, sehingga mahasiswa tidak termotivasi untuk belajar dengan baik di dalam meningkatkan kemampuan atau prestasi belajarnya. Dengan demikian penelitian tindakan kelas ini terbukti telah dapat meningkatkan aspek kognitif dan aspek afektif mahasiswa dalam materi rekonsiliasi bank.

Jadi dengan demikian penerapan Model Pembelajaran TwoStay Two Stray(TSTS)dalam pembelajaran materirekonsiliasi bank telah berhasil dengan baik. Karena itu peneliti menganjurkan bagi dosen-dosen yang mengajarkan mata kuliah akuntansi keuangan pada materi rekonsiliasi bank sebaiknya menerapkan Model Pembelajaran TwoStay Two Stray (TSTS), karena dengan pengalaman yang ada selama ini yaitu dengan menerapkan metode ceramah saja ternyata tidak efektif dalam meningkatkan aktifitas dan hasil belajar mahasiswa. Dengan demikian hasil penelitian ini menunjukkan bahwa Model Pembelajaran TwoStay Two Stray (TSTS telah memberikan hasil berupa ketuntasan belajar mahasiswa. Hal ini membuktikan bahwa berdasarkan penelitian ternyata sebagian besar mahasiswa telah menguasai materi pelajaran yang diajarkan, walaupun tidak seluruhnya. 


\section{E. Kesimpulan dan Saran}

Berdasarkan hasil dan analisis data hasil penelitian yang telah dijelaskan pada bab sebelumnya, maka dapat dikemukakan kesimpulan penelitian ini, yaitu sebagai berikut:

1. Pelaksanaan pembelajaran dengan model pembelajaran TwoStay Two Stray(TSTS) pada siklus I mencapai 97,06\% dimana seluruh tahapan Two Stay Two Stray (TSTS) dapat dilaksanakan dengan baik.

2. Aspek kognitif mahasiswa yang diukur melalui hasil belajar mahasiswa mencakup enam ranah aspek kognitif semester III A kelas Pagi Program Studi Perbankan Syariah Fakultas Agama Islam T.A 2015/ 2016 pada pra tindakanyang mendapat nilai tuntas hanya 14 orang atau $31,82 \%$. Sedangkan pada siklus I jumlah mahasiswa yang mendapatkan nilai tuntas mengalami peningkatan sebanyak 41 orang mahasiswa atau 93,18\%.

3. Aspek afektif mahasiswa pada siklus I mencapai hasil yang diharapkan dalam hal ini diketahui dari 5 indikatornilai total rata-rata aspek afektif yang diperoleh dari lembar observasi pada saat proses pembelajaran adalah 95,4, dengan rincian bahwa aspek penerimaan nilai rata-ratanya sebesar 95; aspek partisipasi nilai rata-ratanya sebesar 93,5; aspek penilaian/penentuan sikap nilai rata-ratanya sebesar 97; aspek organisasi nilai rata-ratanya sebesar 95; aspek pembentukan pola hidup nilai rata-ratanya sebesar 96,5. Dari keseluruhan aspek afektif mahasiswa dari pertemuan siklus I sudah berhasil.

Berdasarkan uraian di atas, dapat disimpulkan bahwa pembelajaran tindakan pada siklus I telah mencapai kriteria yang telah ditetapkan yaitu persentaseaspek kognitif dan aspek afektif mahasiswa untuk belajar dengan menggunakan Model Pembelajaran TwoStay Two Stray (TSTS) juga mendukung mencapai ketuntasan.

Berdasarkan hasil uraian Penelitian Tindakan Kelas (PTK) ini, dan beberapa kesimpulan yang telah diutarakan di atas, ada sejumlah pemikiran yang penulis sarankan yang diharapkan berguna bagi dosen dalam menjalankan fungsinya dan pihak-pihak yang terkait dalam pendidikan, di antaranya:

1. Dengan memperhatikan hakikat dan sifat Model Pembelajaran TwoStay Two Stray (TSTS) sangat berguna untuk meningkatkan aktivitas dan hasil belaja rmahasiswa, maka disarankan kepada dosen supaya memahami model pembelajaran dengan meningkatkan kualitas diri, baik dengan cara belajar atau dengan mengikuti pelatihan-pelatihan peningkatan mutu, untuk kemudian diterapkan dalam proses 
Implementasi Model Pembelajaran Two Stay Two Stray (TSTS) Untuk

Meningkatkan Aspek Kognitif dan Aspek Afektif Mahasiswa Pada Mata Kuliah Akuntansi Keuangan Semester III Kelas A Pagi Program Studi Perbankan Syariah Universitas Muhammadiyah Sumatera Utara Tahun Akademik 2015/ 2016 ( Isra

Hayati )

pembelajaran pada mata pelajaran dan aspek yang tepat.

2. Kepada dosen agar dapat meningkatkan kompetensi dalam mengajar dengan melakukan Penelitian Tindakan Kelas (PTK), sehingga akan ditemukan suatu kondisi belajar yang efektif dan meningkatkan hasil belajar khususnya mahasiswa.

3. Rancangan pembelajaran yang dilakukan dalam penelitian tindakan kelas ini belum sepenuhnya sempurna, untuk itu bagi dosen lain yang ingin mengimplementasikannya dalam materi kreatifitas atau pada materi yang lain hendaknya menelaah terlebih dahulu, sehingga dapat menerapkannya dengan lebih baik.

4. Dalam rangka mencapai tingkat ketepatan penerapan Model Pembelajaran TwoStay Two Stray(TSTS)dalam proses pembelajaran yang lebih inovatif, maka penelitian ini perlu dilanjutkan dengan materi dan pelajaran yang berbeda dan kompetensi yang berfokus pada pendalaman pemahaman, dan keluasan wawasan.

5. Pengambil kebijakan, kiranya mencari jalan keluar untuk meningkatkan kualitas dosen agar mampu mengajar secara profesional dengan memberikan pelatihanpelatihan secara bertahap dan kontinuitas, sehingga para dosen bisa lebih menguasai model, strategi dan metode belajar yang efektif, juga berusaha melengkapi media pembelajaran sehingga memudahkan dosen menyampaikan materi pelajaran yang akhirnya dapat meningkatkan hasil belajar mahasiswa.

\section{Daftar Pustaka}

Anita.(2008). Cooperative Learning: mempraktikkan Cooperative Learning di Ruang-Ruang Kelas. Jakarta: PT Grasindo

Burhan. (2005). Prosedur Penelitian. Jakarta: PT. Rineka Cipta.

Delima.(2011). Penilaian Hasil Proses Belajar Mengajar. Bandung: Remaja Rosdakarya.

Fatirul, A. (2008). "Cooperative Learning". Dalamhttp/trimanjuniarso.file s.wordpress.com, diakses 14 September

Hwang,G.-J.,Yin,P.-Y.,Hwang,C.W.,\& Tsai,C.-C.(2008).“An Enhanced Genetic Approach to Composing Cooperative Learning Groupsfor Multiple Grouping Criteria” .Educational Technology \& Society,11(1),148-167. Dalam http://www.ifest.infol, diakses pada8 Desember2009

Ivana. (2008). Strategi Pembelajaran Aktif. 
Yogyakarta: CSTD

Jagiyanto.(2006), Psikologi Kognitif,

Yogyakarta: Pustaka Pelajar.

Lie.(2002).Mempraktekkan

Cooperative learning di Ruangruang

Kelas.Jakarta:PT.Gramedia.

Moleong, L. J. (2006). Metodologi

Penelitian Kualitatif. Bandung:

PT. Remaja Rosdakarya.

Mulyasa, E. (2006). Kurikulum

Tingkat Satuan Pendidikan.

Bandung:PT

RemajaRosdakarya

Nana. 2003. Dasar-dasar Proses Belajar Mengajar. Bandung: Sinar Baru Algensindo

Nurhadi,dkk.2004.Pembelajaran

Kontekstual dan

Penerapannya dalam KBK.

Malang:UMPress

Ornstein, Allan C. dan Thomas J. Lasley, II. (2000). Strategies for Effective Teaching. TheMcGraw-Hill Higher Education: USA.

Pujiono, S. (2008). "Penguasaan Kosa kata dengan Strategi Jigsaw Pada Siswa SMP."Jurnal Teknodika, 4, No: 153-160

Sari, N.(2009).”Pengaruh Model Pembelajaran STAD dan Penguasaan Kosa kata Bahasa Inggris di Sekolah Dasar".
Jurnal Teknodika, 7, No:1 (3): 80. Surakarta: PPs UNS

Singgih D. (2005). Konseling dan Psikoterapi, Jakarta: Gunung Mulia.

Sugiarto dkk. (2013). Akuntansi Keuangan. Universitas Terbuka: Jakarta

Suprijono,A.(2009). Cooperative Learning Teori dan Aplikasi PAIKEM.Yogyakarta:PustakaPe lajar. 
Implementasi Model Pembelajaran Two Stay Two Stray (TSTS) Untuk Meningkatkan Aspek Kognitif dan Aspek Afektif Mahasiswa Pada Mata Kuliah Akuntansi Keuangan Semester III Kelas A Pagi Program Studi Perbankan Syariah Universitas Muhammadiyah Sumatera Utara Tahun Akademik 2015/ 2016 ( Isra Hayati ) 